Zygmunt Waśkowski

Uniwersytet Ekonomiczny w Poznaniu

\title{
Determinanty decyzji zakupowych nabywców na rynku produktów sportowych
}

\section{THE DETERMINANTS OF PURCHASE DECISIONS OF CUSTOMERS ON THE SPORT PRODUCTS MARKET}

\begin{abstract}
Rynek produktów sportowych $w$ Polsce, dedykowanych dla biegaczy systematycznie rozwija się wraz z liczbq przybywajacych miłośników tej formy spędzania czasu wolnego. Jednakże nabywcy tych produktów wykazuja sie zmiennościq swoich preferencji i zachowań zakupowych, między innymi $w$ zależności od ich doświadczenia biegowego. W artykule dokonano przegladu literatury przedmiotu z obszaru aktywnego wykorzystania czasu wolnego, opracowano autorka propozycję sportowego cyklu życia biegacza, uwzględniajaca jego sposób zachowania na rynku, a także zaprezentowano wyniki badań obrazujace preferencje biegaczy oraz motywy ich decyzji zakupowych w doniesieniu do wybranej grupy produktów, jakq jest obuwie dla biegaczy.
\end{abstract}

Słowa kluczowe: zachowania nabywców, decyzje zakupowe, rynek sportu, rynek biegowy.

\section{Wstęp}

Zachowania nabywców od lat stanowią jeden z ważniejszych obszarów zainteresowań przedstawicieli naukowego środowiska marketingu. Jest to zagadnienie wciąż aktualne i nie w pełni rozpoznane, przede wszystkim z tego względu, że owe zachowania ulegają nieustannym zmianom. Kolejne pokolenia nabywców charakteryzują się innymi postawami, systemami wartości, większą otwartością na zmiany, nowymi sposobami komunikowania się. Ponadto pojawiają się nowe lub wcześniej rzadko spotykane formy aktywności, spędzania czasu wolnego, które na płaszczyźnie rozważań ekonomicznych kreują kolejne rynki branżowe. Przykładem takiej, relatywnie nowej, wciąż słabo rozpoznanej branży jest rynek sportu. Przez wiele lat sport był przedmiotem zainteresowań przedstawicieli nauk o kulturze fizycznej, socjologii, psychologii i medycyny. Dopiero stosunkowo niedawno, w latach 90tych ub. wieku, stał się obiektem badań reprezentantów nauk o zarządzaniu. Potencjał biznesowy, szczególnie sportu profesjonalnego, sprawił, że dostawcy produktów i usług sportowych zaczęli wdrażać orientację marketingową, kierując się oczekiwaniami nabywców, którzy zajęli centralne miejsce w ich strategiach. Natomiast konsumenci aktywnie uprawiający sport zainteresowani nabywaniem specjalistycznych dóbr i usług poszukują ofert w najwyższym stopniu zaspokajających ich potrzeby.

Artykuł uzupełnia aktualny stan stosunkowo ubogiej wiedzy w zakresie zachowań nabywców na rynku sportu. Jego podstawowym celem jest identyfikacja oraz analiza determinant podejmowanych decyzji zakupowych nabywców na rynku sportu w 
segmencie rynku biegowego. Został on przygotowany w oparciu o zgromadzony materiał empiryczny, pochodzący z prowadzonych badań ankietowych.

\section{Zachowania nabywców w czasie wolnym}

Nadrzędną funkcją czasu wolnego człowieka jest wypoczynek i regeneracja sił po wykonanej pracy zawodowej lub wypełnieniu obowiązków rodzinnych. Funkcja ta często jest realizowana równolegle $\mathrm{z}$ podejmowaniem aktywności $\mathrm{w}$ trosce o własny rozwój fizyczny czy duchowy.

Analiza licznych źródeł w postaci doniesień medialnych, artykułów prasowych, literatury fachowej, czy danych historycznych prowadzi do wniosku, że coraz więcej osób z własnego wyboru zaangażuje się w uprawianie sportu ${ }^{1}$. Część z nich ogląda tylko zmagania sportowców, a wiele osób czynnie uprawia sport wskazując na takie powody jak: rekreacja, rozrywka, poprawa kondycji, kształtowanie własnej sylwetki, odreagowanie, czy nawiązywanie kontaktów towarzyskich ${ }^{2} . \mathrm{Z}$ prowadzonych przez $\mathrm{M}$. Bombol badań wynika, że w niektórych przypadkach można mówić o stylu życia, kształtowanym przez zagospodarowanie czasu wolnego uprawianiem sportu ${ }^{3}$. M. Bombol i A. Dąbrowska konstatują, że każdy kto uprawia sport rekreacyjnie czyni to w czasie pozostającym do dyspozycji po wykonaniu obowiązków i zadań związanych z życiem zawodowym lub osobistym ${ }^{4}$. Współcześnie sport i rekreacja $\mathrm{w}$ codziennym życiu odgrywają coraz większą rolę, niezależnie do wieku czy miejsca zamieszkania, mieszkańcy miast i wsi, starsi i młodzież „przyznają się” do uprawiania sportu. Postawy te wpisują się w teorię działania celowego, opracowaną przez Ajzena i Fishbeina, która wyjaśnia, iż uczestnictwo w sporcie jest konsekwencją trzech głównych zmiennych: postawy wobec sportu, postrzeganej akceptacji sportu przez społeczeństwo oraz sprzyjających okoliczności do jego uprawiania ${ }^{5}$.

$\mathrm{Z}$ marketingowego punktu widzenia sympatyk sportu jest nabywca, który w celu zaspokojenia swoich potrzeb związanych z aktywnością fizyczną poszukuje produktu, którego całkowity koszt nabycia będzie niższy od skumulowanych korzyści, jakich doświadczy. Dysponując funduszami, czasem i swobodą wyboru może on sięgnąć po produkty poszukując oferty, która w jego subiektywnej ocenie będzie stanowiła najwyższą wartość ${ }^{6}$. W kontekście tego stwierdzenia należy dodać, że nabywanie

\footnotetext{
1 A. Burlita, Zachowania konsumentów w czasie wolnym i ich uwarunkowania, na przykładzie konsumentów klasy średniej regionu zachodniopomorskiego, Wyd. Uniwersytet Szczeciński, Szczecin 2006, s. 225 ; B. Sojkin, (red.), Sport w Poznaniu i Wielkopolsce, Wyd. Uniwersytetu Ekonomicznego w Poznaniu, Poznań 2010, s. 33-35; Forbes, czerwiec 2015 r. s. 41.

${ }^{2}$ J. Klisiński, Marketing w biznesie sportowym, Wyższa Szkoła Ekonomii i Administracji w Bytomiu, Bytom 2008, s. 31.

${ }^{3}$ M. Bombol., Ekonomiczny wymiar czasu wolnego, Wyd. Szkoła Głowna Handlowa, Warszawa 2005, s. 131133; Profil polskiego biegacza, Raport z badań, Uniwersytet Ekonomiczny w Poznaniu, Poznań 2014.

4 M. Bombol, A. Dąbrowska, Czas wolny, Konsument, Rynek, Marketing, Wydawnictwo K.E. Liber, Warszawa 2003, s. 5.

${ }^{5}$ M. Jarvis, Psychologia sportu, Gdańskie Wydawnictwo Psychologiczne, Gdańsk 2003, s. 42-43, za: J. Ajzen, M. Fishbein, Understanding attitudes and predicting social behavior, England Cliffs, Prentice Hall, 1998.

${ }^{6}$ M.J. Morgan, J. Summers, Sport Consumption: Exploring the Duality of Constructs in Experiential Research, w: Sharing Best Practice in Sport Marketing, ed. B.G. Pitts, Fitness Information Technology, Inc., Morgantown 2004, s. $167-177$.
} 
produktów sportowych przez konsumentów aktywnie spędzających czas wolny jest wynikiem procesu podejmowania swobodnych decyzji zwiąanych $\mathrm{z}$ zamiarem zaspokojenia potrzeb psychicznych, społecznych, a także fizycznych.

B. Mullin. S. Hardy i W. Sutton opracowali model zachowań nabywców na rynku sportu, bazując na środowiskowych i osobowych determinantach. Badacze wyłonili trzy stadia relacji łączące nabywców ze sportem: socjalizację, więzi i zaangażowanie ${ }^{7}$. Socjalizacja, dzięki przyswojeniu sobie konkretnej wiedzy i umiejętności, pozwala na pełnienie określonych ról społecznych, np. opierających się na więzi ze sportem. Badacze wymieniają trzy rodzaje więzi ze sportem. Więzi behawioralne dotyczą takich zachowań, jak aktywność ruchowa, udział w zawodach sportowych, dopingowanie zawodników. Więzi kognitywne wynikają $\mathrm{z}$ chęci zdobywania wiedzy, poznawania nowych faktów i lepszego rozumienia zdarzeń. Z kolei więzi afektywne pojawiają się wówczas, gdy nabywca w sposób emocjonalny angażuje się w sport, jest skłonny przyjąc skrajnie negatywną lub pozytywną postawę wobec np. jakiegoś wydarzenia lub drużyny sportowej. Natomiast zaangażowanie odwołuje się do częstotliwości, czasu trwania oraz intensywności więzi ze sportem, a także gotowości przeznaczania pieniędzy na sport, poświęcania czasu na jego uprawianie oraz wydatkowanie energii na eksponowanie przywiązania do sportu.

\section{Cykl życia biegacza}

Rynek biegowy, analogiczne do rynku sportu, można zdefiniować jako ogół stosunków wymiany zachodzących między nabywcami i dostawcami oferującymi im produkty sportowe mające postać dóbr materialnych lub usług, których konsumpcja ma zaspokoić potrzeby związane $\mathrm{z}$ bieganiem ${ }^{8}$. Uczestnikami tworzącymi popytową część tego rynku są osoby uprawiające biegi oraz, w znacznie mniejszym zakresie, osoby, które można określić kibicami biegaczy ${ }^{9}$. Dalsze rozważania w artykule będą koncentrowały się na segmencie nabywców uprawiających biegi amatorsko. Liczba biegaczy w Europie szacowana jest na ponad 50 milionów osób, które każdego roku na cele związane z tą aktywnością przeznaczają 9,6 mld EUR ${ }^{10}$. W Polsce w ostatniej dekadzie liczba biegaczy diametralnie wzrosła, według różnych źródeł szacuje się, że w naszym kraju regularnie biegają blisko 3 miliony osób, które na tą aktywność wydają rocznie około 1,8 mld PLN ${ }^{11}$. Co ważne, rynek biegowy wykazuje cały czas tendencję wzrostową, przez co jest bardzo atrakcyjny dla producentów zarówno krajowych, jak i międzynarodowych koncernów ${ }^{12}$.

\footnotetext{
${ }^{7}$ B.J. Mullin, S. Hardy, W.A. Sutton, Sport Marketing, Human Kinetics, Champaign, 2000, s. $56-75$.

${ }^{8}$ Z. Waśkowski (red.), Marketing imprez biegowych, Bogucki Wydawnictwo Naukowe, Poznań 2014 r., s. 10.

${ }^{9}$ K. Koronios, M. Psiloutsikou, A. Kriemadis, What motivates repeated participation in ultraendurance events? A comparison between runners and cyclists, Business \& Entrepreneurship Journal, vol. 5, no. 2, 2016 r., 17-34

${ }^{10}$ J. Scheerder, K. Breedveld, A. Danchev, (ed.) Running acoross Europe, Palgrave MacMillan UK, 2015 r. s. 34.

${ }^{11}$ Forbes, czerwiec 2015 r. s. 41.

${ }^{12}$ Running USA, Annual Report, 2015.
} 
Nabywcy z zamiłowaniem do biegania stanowią bardzo zróżnicowaną wewnętrznie grupe, o różnych umiejętnościach sportowych i wynikających $z$ tego potrzebach ${ }^{13}$. Wpływa to $\mathrm{w}$ istotny sposób na ich zachowania na rynku, w tym podejmowane decyzje zakupowe $^{14}$. Aktywność fizyczna biegacza zwykle zmienia się w czasie. Można ją porównać do modelu cyklu życia produktu i analogicznie wyróżnić cztery fazy życia biegacza (rys. 1).

Rysunek 1. Cykl życia biegacza

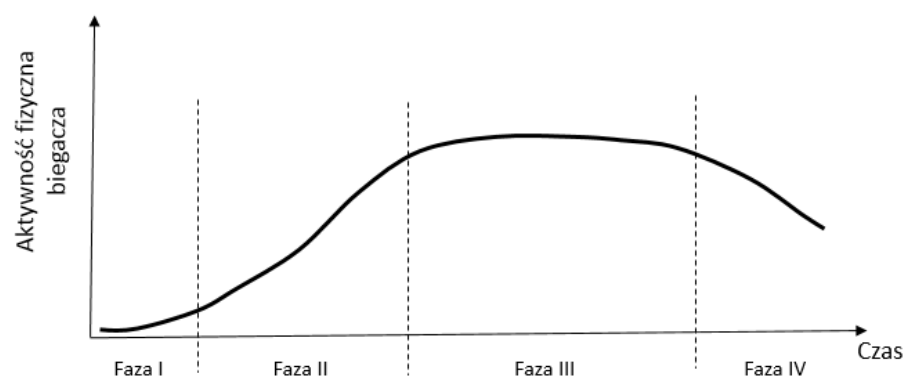

Źródło: opracowanie własne.

W poszczególnych fazach ww. cyklu pasjonaci biegów wykazują się odmienną intensywnością i różnorodnością zgłaszanych potrzeb, co w skali makro przekłada się na potencjał $\mathrm{i}$ atrakcyjność rynku biegowego $\mathrm{z}$ punktu widzenia podmiotów reprezentujących jego podażową część.

a. Faza I Zainteresowanie - biegacze zaczynają swoją przygodę z bieganiem, dopiero odkrywają ten sport i wiążące się z tym przyjemności oraz potrzeby. Ich poziom wiedzy zarówno na temat biegania, jak i oferty dla biegaczy jest bardzo niski, a oczekiwania wobec siebie i wobec dostawców nie są wygórowane. W miarę swoich możliwości finansowych testują nowe produkty sportowe, są podatni na komunikaty promocyjne ${ }^{15}$.

b. Faza II Fascynacja - biegacze zaczynają bardziej interesować się tajnikami biegania, uprawiają sport regularnie, nabywają więcej i coraz lepszej jakości akcesoriów dla biegaczy, są aktywni w social mediach, podejmują dyskusje, szukają i dzielą się zdobytymi informacjami, ich wiedza na temat sportu jest już większa, chętnie reagują na działania marketingowe producentów, choć mają bardziej wyrobione oczekiwania ${ }^{16}$.

c. Faza III Dojrzałość - biegacze są lojalni wobec wybranych marek, nabywają tylko sprawdzony sprzęt, akcesoria i odżywki, nie poddają się łatwo zachętom

\footnotetext{
${ }^{13}$ P. Zawadzki, Masowe imprezy biegowe jako element promocji regionów turystycznych, Prace Naukowe Uniwersytetu Ekonomicznego we Wrocławiu, Gospodarka turystyczna w regionie. Przedsiębiorstwo, Samorząd, Współpraca, nr 379, 2015 r., s. 311-319.

${ }^{14}$ E.C. Schwarz, J.D. Hunter, Sport Marketing, Butterworth-Heinemann. Burlington, 2008 r. s. 106-107; D.C.

Funk, Customer Behaviour in Sport and Events, Butterworth-Heinemann, Burlington, 2008 r., s. 16-21.

${ }^{15}$ Karhu Runners Industry Report, Brookmark Research, Marblehead, 2012 r.

${ }^{16}$ Profil polskiego biegacza, Raport z badań, Uniwersytet Ekonomiczny w Poznaniu, Poznań 2014 r.
} 
nieznanych producentów, mają szeroką, gromadzoną z różnych źródeł wiedzę na temat biegania, diety, imprez biegowych i dostępności produktów dla biegaczy, dzielą się swoimi doświadczeniami i inspirują innych do uprawiania tej formy rekreacji ruchowej, na bieganie poświęcają relatywnie sporą część swoich dochodów.

d. Faza IV Schyłek - aktywność biegaczy w tej fazie maleje, rezygnują oni z części wcześniej ,obowiązkowo" nabywanych produktów, są mniej wyczuleni na nowości rynkowe, nie chłoną już tak mocno jak wcześniej informacji dotyczących biegania, ograniczają swoje kontakty ze środowiskiem pasjonatów tego sportu, z różnych względów nie biegają już tak dużo i regularnie jak wcześniej.

Oprócz znajomości zachowań nabywców nie mniej ważna jest wiedza na temat determinant ich decyzji zakupowych. Na tej podstawie przedsiębiorstwa mogą trafniej oddziaływać na wybrane segmenty rynku skupiając wokół własnej marki lojalnych klientów i umacniając swoją przewagę konkurencyjną ${ }^{17}$.

\section{Metodyka i wyniki badań}

Autor artykułu realizuje projekt badawczy, który zakłada okresowe badanie aktywności sportowej polskich biegaczy oraz związanych z tym ich zachowań zakupowych. Badania zgodnie $\mathrm{z}$ założeniem są prowadzone $\mathrm{w}$ cyklu dwuletnim, co $\mathrm{w}$ dłuższej perspektywie pozwoli na dokonywanie analiz komparatywnych oraz monitorowanie zachodzących $w$ ww. zakresie zmian. Do tej pory przeprowadzono dwie edycje mających ogólnopolski zasięg badań: w 2014 roku na próbie 4406 biegaczy i w 2016 roku na próbie 1545 biegaczy. Informacje gromadzone sa za pomocą elektronicznego kwestionariusza ankietowego, dobór respondentów odbywa się losowo, z tego względu mimo dość licznych grup badanych biegaczy nie można uogólniać uzyskanych wyników na całą populację. Tym niemniej materiał empiryczny pozwala na formułowanie wniosków opisujących rzeczywiste zachowania zakupowe dużego segmentu osób aktywnie spędzających czas wolny oraz identyfikacji ich oczekiwań wobec nabywanych dóbr związanych z tym rodzajem sportu. Informacje te $\mathrm{z}$ jednej strony mogą być użyteczne do opisu zjawisk społecznych, a $\mathrm{z}$ drugiej strony mają wysoką wartość poznawczą $\mathrm{w}$ środowisku naukowym marketingu.

Wśród kilkudziesięciu znajdujących się w kwestionariuszu ankietowym pytań, część dotyczy preferencji i zachowań zakupowych nabywców. Na potrzeby realizacji przyjętego w artykule celu wykorzystano tylko wybrane wyniki badań przeprowadzonych w 2016 roku, gdyż analiza porównawcza z wynikami badań z 2014 roku w zakresie tych pytań nie wykazała istotnych różnic.

Respondentów zapytano między innymi na co zwracają uwagę kupując obuwie do biegania. Kafeteria odpowiedzi obejmowała następujące kryteria: cena, marka, design, amortyzacja, typ obuwia (startowe, treningowe, trailowe, do biegania naturalnego), waga, rekomendacja sprzedawcy, aktualne promocje (np. wyprzedaże). Badani oceniali ww. kryteria w skali punktowej od 1 - w ogóle nie zwracam uwagi, do 5 - bardzo zwracam uwagę. Strukturę zebranych odpowiedzi zaprezentowano na wykresie 1.

17 A.L. Mihai, The Sport Marketing Management Model, Practical Application of Science, Volume 3, Issue 2(8), 2015 r. s. $297-301$. 
Wykres 1. Kryteria wyboru obuwia do biegania

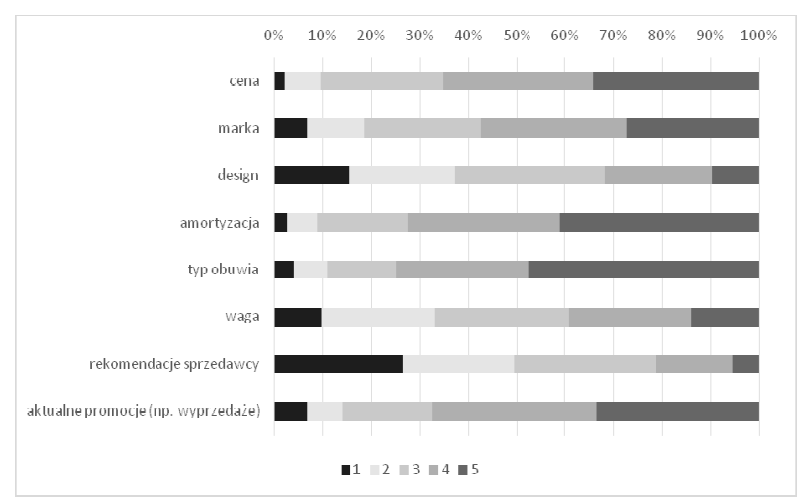

Źródło: badania własne, 2016 r.

Na dwóch pierwszych miejscach pod względem ważności uplasowały się typ obuwia i amortyzacja, że średnią ocen odpowiednio 4,07 i 4,01. Zatem najważniejszymi kryteriami wyboru butów do biegania są te związane z parametrami technicznymi. Oznacza to, że polscy biegacze przywiązują dużą wagę do zdrowia, gdyż obydwa ww. parametry mają bezpośredni związek z ryzykiem wystąpienia kontuzji sportowca. Kolejne dwa miejsca pod względem ważności zajmują kryteria związane z kosztami. tj. wysokość cen oraz możliwość zakupu na wyprzedaży. W tym przypadku średnie ocen wyniosły 3,87 i 3,80. Dopiero na piątym miejscu, wyraźnie mniej istotnym kryterium jest marka butów (średnia ocen 3,59). Ostatnie miejsce rekomendacji sprzedawcy w rankingu kryteriów (średnia ocen 2,50) świadczy o niskim zaufaniu do osób, których zadaniem jest przede wszystkim sprzedaż produktów znajdujących się w sklepie. Struktura uzyskanych odpowiedzi może świadczyć o tym, że większość amatorów biegania w Polsce znajduje się w pierwszej lub drugiej fazie życia biegacza. Są oni już świadomi znaczenia jakości obuwia biegowego (parametry techniczne), jednocześnie bardziej kierują się ceną niż marką producenta. Oznacza to, że nie mają jeszcze wyrobionej opinii o obecnych na rynku producentach i nie wykazują wysokiej lojalności wobec dostępnych marek. Ten ostatni wniosek potwierdza struktura odpowiedzi na inne zadane respondentom pytanie, dotyczące prestiżu 13 wymienionych marek. W przypadku aż 5 z nich odnotowano odpowiedź „nie znam” na poziomie $20 \%$ lub wyższym.

W badaniu pytano też respondentów skąd, w procesie podejmowania decyzji zakupowych, czerpią informacje na temat sprzętu i akcesoriów do biegania. Kafeteria odpowiedzi w tym przypadku obejmowała następujące źródła informacji: sprzedawca w sklepie, Internet, znajomi biegacze, trener, czasopisma/książki, rekomendacje słynnych biegaczy, własne doświadczenia, reklama, cena, obecność produktu w aplikacjach mobilnych. Na wykresie 2 zaprezentowano strukturę uzyskanych odpowiedzi. 
Wykres 2. Źródła informacji na temat oferty handlowej

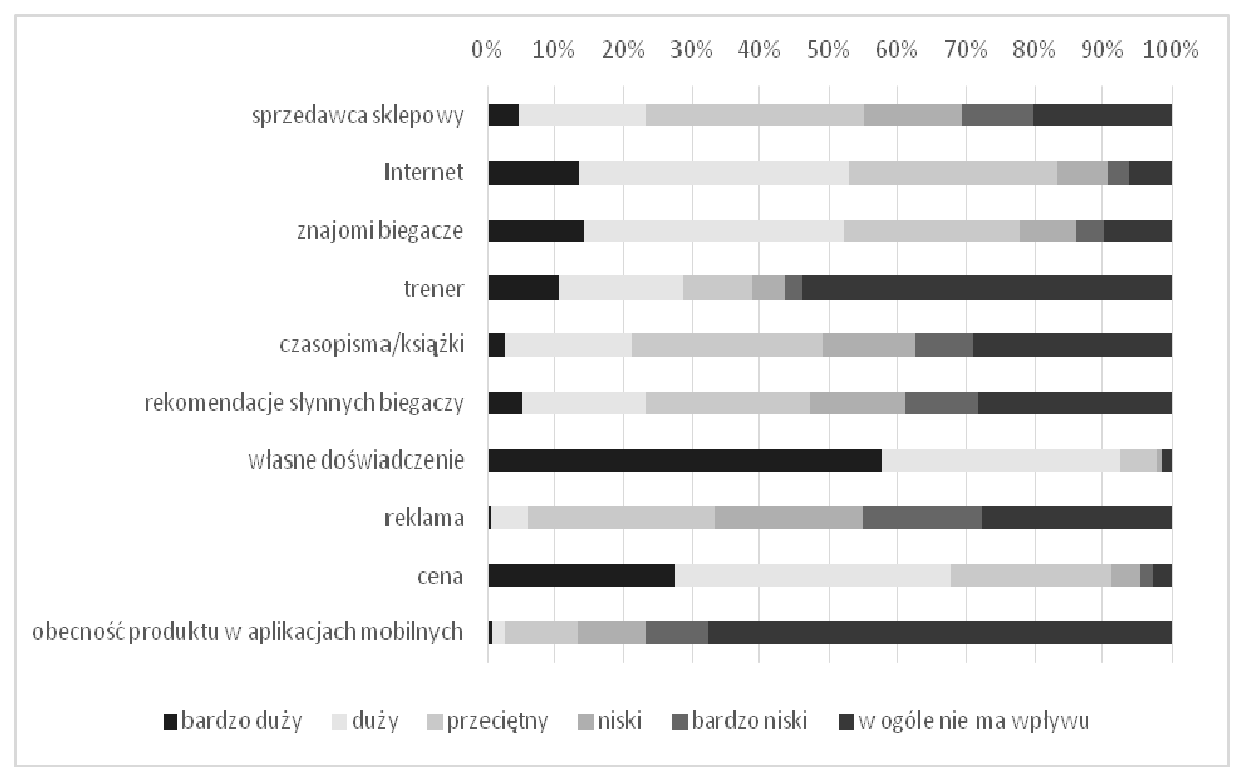

Źródło: badania własne, 2016 r.

Polscy biegacze, podejmując decyzje zakupowe, kierują się przede wszystkim własnym doświadczeniem, co oznacza, że nabywają te produkty, które wcześniej się sprawdziły. Przewaga tego źródła informacji nad pozostałymi jest zdecydowana. Większość osób aktualnie uprawiających biegi znajduje się przed fazą dojrzałości, w której biegacze mają już wyrobione preferencje i cechują się lojalnością wobec marek. Potwierdziły to zarówno badania prowadzone przez Autora artykułu jak i badania innych zespołów badawczych [Polska Biega 2015]. Jest to ważna informacja m.in. dla producentów sprzętu sportowego, którzy powinni swoje wysiłki koncentrować przede wszystkim na zachęcaniu biegaczy do testowania ich produktów. Na kolejnym miejscu pod względem ważności w procesie podejmowania decyzji zakupowej uplasowała się cena. Warto w tym miejscu dodać, że obuwie sportowe w Polsce jest relatywnie drogie w stosunku do cen tych produktów spotykanych w krajach zachodnich, co przy niższych dochodach ma dla biegaczy niebagatelne znaczenie. Na dwóch następnych miejscach uplasowały się źródła informacji związane $\mathrm{z}$ tzw. pocztą pantoflową, tj. porady znajomych oraz opinie w Internecie. Badania potwierdziły, że biegacze znacznie bardziej ufają nieformalnym informacjom, niż tym o charakterze komercyjnym, np. pochodzącym z reklam czy aplikacji mobilnych.

Wielu respondentów wypowiedziało się, że trener nie ma w ogóle wpływu na ich decyzje zakupowe. Wynika to prawdopodobnie z faktu, iż w Polsce tylko nieliczni biegacze korzystają z usług specjalistów przygotowujących dla nich plany treningowe oraz konsultujących postępy w bieganiu. Usługi tego typu nie są w naszym kraju jeszcze tak bardzo rozpowszechnione, ale należy się spodziewać, że w najbliższej przyszłości ich popularność będzie rosła. Warto jednak zauważyć, że to samo źródło informacji jest bardzo ważne dla blisko $30 \%$ badanych, co oznacza, że jeśli trener doradza biegaczowi 
w zakresie ćwiczeń to jednocześnie staje się jego autorytetem w zakresie wyboru sprzętu sportowego. Badania wykazały, że na decyzje zakupowe respondentów umiarkowany wpływ mają informacje pochodzące $\mathrm{z}$ czasopism specjalistycznych, książek, rekomendacje znanych sportowców oraz porady sprzedawcy sklepowego.

\section{Rekomendacje dla praktyki gospodarczej i dalsze kierunki badań}

$\mathrm{Na}$ podstawie zgromadzonego materiału empirycznego można sformułować kilka wniosków o charakterze aplikacyjnym. Dostawcy produktów sportowych dedykowanych dla segmentu biegaczy powinni:

a. w większym stopniu zadbać o dostępność ich produktów w sklepach detalicznych,

b. uczynić cenę istotnym narzędziem walki konkurencyjnej,

c. kształtować swój wizerunek w komercyjnych kanałach komunikacji marketingowej, natomiast biegaczy zachęcać do zakupu przez niestandardowe formy komunikacji,

d. rozwijać aktywność w social mediach m.in. przez wykorzystanie marketingu wirusowego,

e. wprowadzać programy lojalnościowe, które będą premiowały użytkowanie produktów producenta (lub producentów),

f. budować sieć ambasadorów marki wśród znanych biegaczy lub trenerów personalnych,

g. systematycznie udoskonalać swoje produkty pod względem parametrów technicznych.

Przeprowadzone badania pozwalają lepiej zorientować się w motywach i zachowaniach zakupowych nabywców. Jednocześnie w segmencie rynku biegowego jest jeszcze wiele aspektów, które mogłyby stać się przedmiotem kolejnych badań tego rynku. W świetle zgormadzonego materiału empirycznego jako dalsze, pożądane kierunki badań można wskazać m.in. zmiany zachowań zakupowych w poszczególnych fazach cyklu życia biegacza, determinanty lojalności nabywców wobec marek sportowych, powszechność i skutki występowania tzw. efektu RoPo (research online purchase offline) i odwróconego efektu RoPo, gotowość nabywców do poszerzania portfela produktów tej samej marki (tzw. cross-selling), a także warunki i sposoby użytkowania nabywanych produktów.

\section{Podsumowanie}

Rynek biegowy w Polsce od kilku lat znajduje się w fazie wzrostu, należy się jednak spodziewać, że niebawem zmiany ilościowe ustąpią miejsca zmianom jakościowym. Nastapi m.in. zahamowanie przyrostu liczby osób uprawiających biegi, organizowanych imprez biegowych, czy otwieranych specjalistycznych sklepów detalicznych. Z pewnością nadal będzie on atrakcyjny dla producentów jako obszar penetracji i pomnażania przychodów, a dla przedstawicieli nauki jako intersujący obiekt badań. Liczne grono biegaczy zgłaszających potrzeby związane z tym sportem, reprezentujące niemały $\mathrm{w}$ ujęciu wartościowym potencjał, jak również zmiany zachodzące $\mathrm{w}$ ich postępowaniu $\mathrm{w}$ poszczególnych fazach życia sprawiaja, że wiedza na temat ich 
preferencji i determinant decyzji zakupowych jest niezwykle pożądana. Zarówno wysoka wartość tego rynku, przewidywane, dalsze zmiany w strukturze jego podmiotów i ich aktywności zachęcają do prowadzenia kolejnych obserwacji oraz analiz. Usystematyzowana wiedza $\mathrm{z}$ tego zakresu będzie wzbogacała dotychczasowy dorobek literatury przedmiotu na temat zachowań nabywców.

\section{Bibliografia}

Ajzen J., Fishbein M., Understanding attitudes and predicting social behavior, England Cliffs, Prentice Hall. 1998. Bombol M., Ekonomiczny wymiar czasu wolnego, Wyd. Szkoła Głowna Handlowa, Warszawa 2005.

Bombol M., Dąbrowska A., Czas wolny, Konsument, Rynek, Marketing, Wydawnictwo K.E. Liber, Warszawa 2003. Burlita A., Zachowania konsumentów w czasie wolnym i ich uwarunkowania, na przykładzie konsumentów klasy średniej regionu zachodniopomorskiego, Wyd. Uniwersytet Szczeciński, Szczecin, 2006.

Forbes, czerwiec 2015.

Funk D.C., Customer Behaviour in Sport and Events, Butterworth-Heinemann, Burlington, 2008.

Jarvis M., Psychologia sportu, Gdańskie Wydawnictwo Psychologiczne, Gdańsk, 2003.

Karhu Runners Industry Report, Brookmark Research, Marblehead, 2012.

Klisiński J., Marketing w biznesie sportowym, Wyższa Szkoła Ekonomii i Administracji w Bytomiu, Bytom, 2008.

Koronios K, Psiloutsikou M., Kriemadis A., What motivates repeated participation in ultraendurance events? A comparison between runners and cyclists, Business \& Entrepreneurship Journal, vol. 5, no. 2, 2016.

Mihai A.L., The Sport Marketing Management Model, Practical Application of Science, Volume 3, Issue 2(8), 2015.

Morgan M.J., Summers J., Sport Consumption: Exploring the Duality of Constructs in Experiential Research, w: Sharing Best Practice in Sport Marketing, ed. B.G. Pitts, Fitness Information Technology, Inc., Morgantown, 2004.

Mullin B.J., Hardy S., Sutton W.A., Sport Marketing, Human Kinetics, Champaign, 2000.

Profil polskiego biegacza, Raport z badań, Uniwersytet Ekonomiczny w Poznaniu, Poznań, 2014.

Running USA, Annual Report, 2015.

Scheerder J., Breedveld K., Danchev A., (ed.), Running acoross Europe, Palgrave MacMillan UK, 2015.

Schwarz E.C., Hunter J.D., Sport Marketing, Butterworth-Heinemann. Burlington, 2008.

Sojkin B., (red.), Sport w Poznaniu i Wielkopolsce, Wyd. Uniwersytetu Ekonomicznego w Poznaniu, Poznań, 2010. Waśkowski Z., (red), Marketing imprez biegowych, Bogucki Wydawnictwo Naukowe, Poznań, 2014.

Zawadzki P., Masowe imprezy biegowe jako element promocji regionów turystycznych, Prace Naukowe Uniwersytetu Ekonomicznego we Wrocławiu, Gospodarka turystyczna w regionie. Przedsiębiorstwo, Samorząd, Współpraca, nr 379, 2015.

\section{Summary}

The Polish market of sport products dedicated for runners systematically develops as the number of people who choose this way of passing their leisure time increases. However, the customers who buy these products have varying preferences and behaviours, depending on, among others, their running experience. This article contains an overview of literature on the subject of active leisure time. It also presents the Author's original idea for a runner's sports life cycle, which includes their market behaviour, and the results of own research which show the runners' preferences and motivations when it comes to making purchase decisions on the example of a chosen product group, namely: runners' shoes.

Key words: customer behaviors, purchase decisions, sport market, running industry.

\section{Informacje o autorze:}

dr hab. Zygmunt Waśkowski, prof. nadzw. UEP

Wydział Zarządzania

Uniwersytet Ekonomiczny w Poznaniu

e-mail: Zygmunt.Waskowski@ue.poznan.pl 